Reprod. Nutr. Dévelop., 1983, 23 (3), 509-515.

\title{
$\beta$-Aspartyl- $\varepsilon$-lysine, a peptide of the fecal contents of axenic mice
}

\author{
J.-P. PÉLISSIER, Françoise DUBOS $\left({ }^{*}\right)$
}

Laboratoire de Biochimie et Technologie laitières,

(*) Laboratoire d'Ecologie Microbienne,

I.N.R.A., 78350 Jouy-en-Josas, France.

Summary. Small quantities of low-molecular weight peptides have been characterized in the feces of axenic mice. In fecal material of axenic mice fed an autoclaved synthetic (SN) diet, we isolated a dipeptide and characterized its structure as $\beta$-aspartyl- $\varepsilon$-lysine. This product was also present in the feces of gnotobiotic mice harbouring Clostridium perenne. We could not detect the product in the fecal contents of holoxenic mice, Clostridium difficile-contaminated mice or axenic mice fed the irradiated $\mathrm{SN}$ diet.

The peptide, $\beta$-aspartyl- $\varepsilon$-lysine, was produced by heating proteins during sterilization, causing the formation of a pseudopeptide bond between the $\varepsilon$-amino group of lysine and the amide group of asparagine. The intestinal strains seemed to differ in their ability to split this pseudopeptide bond in vivo.

\section{Introduction.}

The fecal microbial flora of newborn mammals seems to depend largely on their diet, which varies between birth and weaning (Decuypere and Van Der Heyde, 1972 ; Chopin et al., 1974 ; Ducluzeau et al., 1974 ; Savage, 1977). As shown by Ducluzeau et al. (1981), a strain of Clostridium perenne did not establish when axenic mice were fed with a " non-permissive " diet, but it did establish when they were fed a " permissive " diet. Once this strain had been established in animals fed a permissive diet, it persisted in the dominant flora, even if the permissive diet was replaced by a non-permissive one (Ducluzeau et al., 1981).

The supernatant of fecal and cecal contents of mice contains free amino acids. Higher amounts of free amino acid have been found in the cecal contents of axenics than in those of conventional mice (Combe et al., 1965). Only one low-molecular weight peptide substance, $\beta$-aspartylglycine has been characterized in the cecal contents of axenic mice (Welling and Groen, 1978 ; Welling et al., 1980).

The fecal or cecal digestive content of axenic animals fed with the nonpermissive diet in vivo inhibits the growth of $C$. perenne (Dubos, 1982). The present paper describes the isolation and characterization of a low-molecular weight peptide in the inhibitory fraction of the fecal contents of axenic mice fed a non- 
permissive diet. We have also tried to determine if the presence of this peptide in the gut depended on the bacterial strain harboured. The effect of this peptide on the growth of $C$. perenne has been studied by Dubos (1982).

\section{Experimental protocol}

Products. $-\alpha$-L-aspartylglycine, $\beta$-L-aspartylglycine and $\alpha$-L-aspartyl- $\varepsilon-\mathrm{L}$ lysine were from Bachem (Budendorf, Switzerland); dansyl chloride was from Fluka AG (Buchs, Switzerland) : Sephadex G25 was from Pharmacia (Uppsala, Sweden) ; Whatman 3MM chromatography paper was from Whatman (Maidstone, Kent, England) ; ninhydrin was from Merck (Darmstadt, West Germany) and 2,4,6 collidin was from Sigma (St Louis, Mo., USA). All the other products were from Prolabo (Paris, France).

Animals. - Adult axenic $\mathrm{C} 3 \mathrm{H}$ mice were reared in plastic Trexler-type isolators. Gnotobiotic mice harbouring Clostridium strains were reared in the same type of isolators.

Diets. - Axenic mice were fed ad libitum a semi-synthetic (SN) diet containing (in $\mathrm{g} / \mathrm{kg}$ ) : $220 \mathrm{~g}$ of casein, $580 \mathrm{~g}$ of cornstarch, $90 \mathrm{~g}$ of corn oil, $50 \mathrm{~g}$ of cellulose and $45 \mathrm{~g}$ of a mineral and vitamin mixture; this diet was sterilized by autoclaving at $120^{\circ} \mathrm{C}$ for $20 \mathrm{~min}$. The same diet without casein was used as a protein-free (PF) diet. The SN diet and a commercial one (UAR $n$ R03) sterilized by $\gamma$-irradiation (4 $\mathrm{M}$ rad) were also given.

Bacterial strains. - A strain of C. perenne and one of Clostridium difficile from the collection of the "Laboratoire d'Ecologie Microbienne " were cultured on a standard liquid medium for anaerobes. Axenic mice were inoculated per os with a 24-hour culture of $C$. difficile or C. perenne.

Isolation of low-molecular weight substances. - Batches of fecal contents were prepared by pooling $20 \mathrm{~g}$ of the fresh feces of 10 axenic mice. The products were mixed with $40 \mathrm{ml}$ of water and homogenized in an Ultraturrax (Garantlab-Turrax, Paris, France). The supernatants were obtained by centrifugation at $20000 \times \mathrm{g}$ for $10 \mathrm{~min}$ and then stored at $-25^{\circ} \mathrm{C}$.

$100 \mathrm{ml}$ of the supernatant were applied to a Sephadex G25 (fine) column $(3 \times 180 \mathrm{~cm})$ and eluted at a flow rate of $20 \mathrm{ml} / \mathrm{h}$ with $30 \%(\mathrm{v} / \mathrm{v})$ acetic acid. $10-\mathrm{ml}$ fractions were collected.

$100 \mu \mathrm{l}$ of the fractions were spotted on Whatman 3MM paper and subjected to high-voltage paper electrophoresis at $\mathrm{pH} 1.9$ (formic acid/acetic acid/water, 25:87:888, v/v/v) for $30 \mathrm{~min}$ at $53 \mathrm{~V} / \mathrm{cm}$. A reference mixture (Beckman, Palo Alto, USA) containing all the common amino acids were used. After drying at $55^{\circ} \mathrm{C}$, the paper was coloured with a ninhydrin-collidine solution (ninhydrin/ collidine/ethanol ; $1 \mathrm{~g}, 50 \mathrm{ml}, 950 \mathrm{ml}$ ) and heated at $55^{\circ} \mathrm{C}$ for $5 \mathrm{~min}$.

Preparative high-voltage electrophoresis was carried out at $\mathrm{pH} 1.9$. The products were eluted from paper with $30 \%$ acetic acid. 
Identification of the peptide substance. - Amino acid analysis was performed with a Multichrom amino acid analyzer (Beckman, München, West Germany). The samples were hydrolyzed in $1.5 \mathrm{ml}$ of $5.7 \mathrm{~N} \mathrm{HCl}$ at $110^{\circ} \mathrm{C}$ in evacuated, sealed glass-tubes for $24 \mathrm{~h}$. N-terminal amino acid was determined as described by Hartley (1970). Mass spectrometry was obtained on a Nermag R10R10.

\section{Results}

Fractions of axenic mice fed the autoclaved $\mathrm{SN}$ diet were obtained by Sephadex chromatography. Using high-voltage paper electrophoresis, we detected, in the inhibitory fraction, a ninhydrin reactive product migrating between free alanine and free glycine (fig. 1). This product was eluted from the Sephadex G25 just before the major part of the free amino acids.

When the same purifications were carried out on the fecal contents of gnotobiotic mice harbouring $C$. perenne and fed the autoclaved SN diet, the same spot in about equal amounts was observed. The product was not seen (fig. 2) in fractions of conventional mice or gnotobiotic mice harbouring $C$. difficile and fed the autoclaved SN diet.

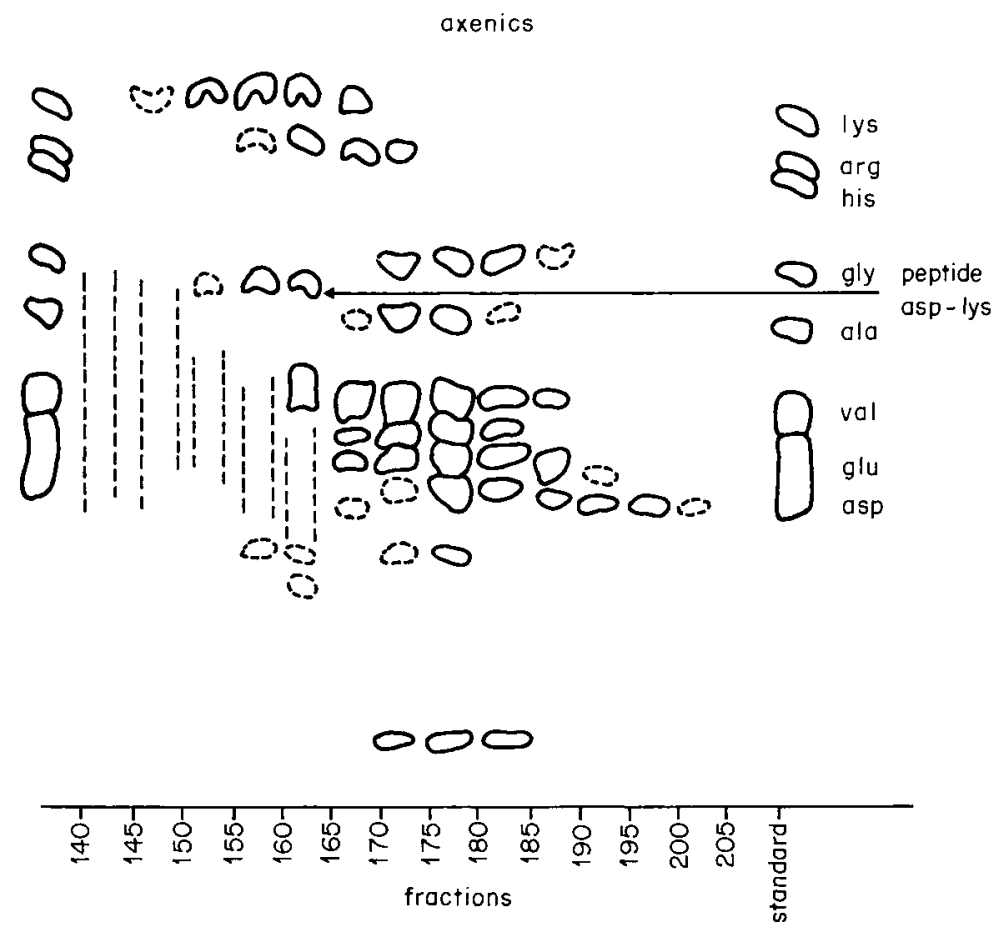

FIG. 1. - Paper electrophoretic analysis $(\mathrm{pH} 1.9)$ of fractions of the fecal contents of axenic mice obtained by chromatography on Sephadex G25. 

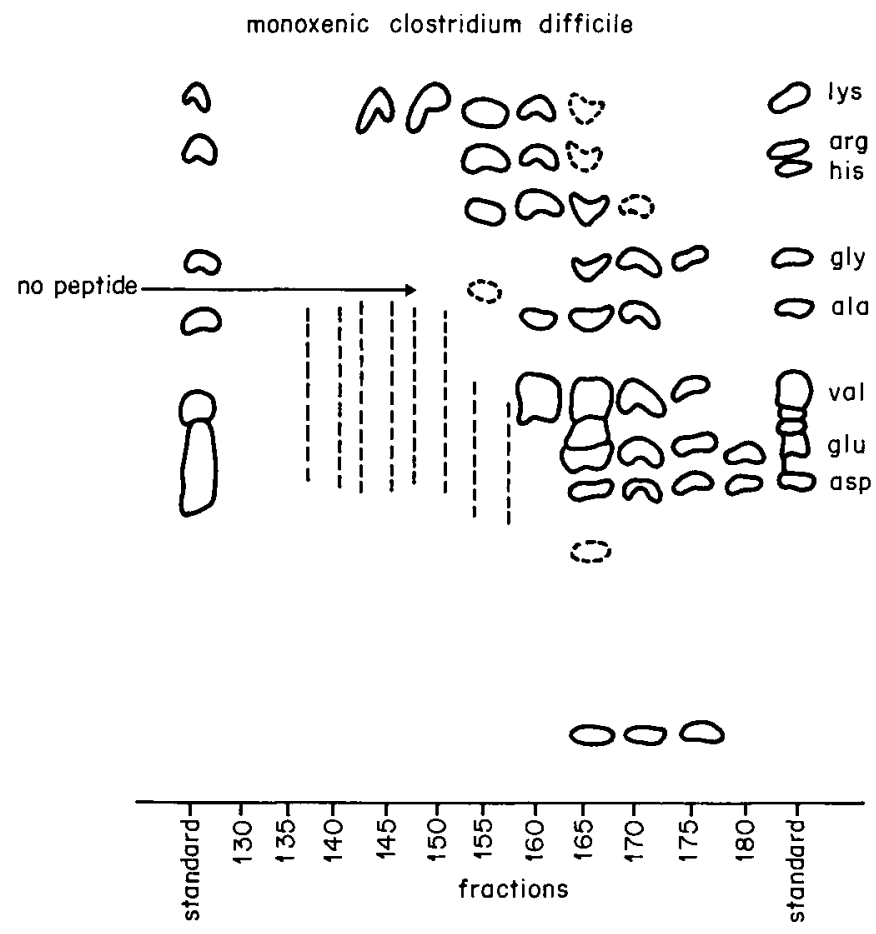

FIG. 2. - Paper electrophoretic analysis (pH 1.9) of fractions of the fecal contents of monoxenic mice harbouring Clostridium difficile obtained by chromatography on Sephadex G25.

We did not find the peptide with the PF diet. With the irradiated SN diet, we obtained significantly lower quantities of the peptide than with the same diet sterilized by heat. We did not find significant quantities of the peptide in the diets themselves analyzed by the same method.

After acid hydrolysis, the substance purified by paper electrophoresis gave equal amounts of aspartic acid and lysine by amino acid analysis. The molecular weight obtained by mass spectrometry was that of a dipeptide composed of one residue of aspartic acid and one residue of lysine. Dansylation and subsequent hydrolysis showed the $\mathrm{N}$-terminal amino acid to be aspartic acid.

Under high-voltage paper electrophoresis, commercial $\alpha$-aspartylglycine and $\beta$-aspartylglycine migrated to the same position but, as observed by Welling and Groen (1978), they did not give the same colour. On the other hand, commercial $\alpha$-aspartyl $\alpha$-lysine was less acidic than our peptide which migrated as commercial $\alpha$-aspartyl $\varepsilon$-lysine.

\section{Discussion.}

Peptide structure. - We could not identify the amino acids present in the product with the amino acid composition of the peptide obtained by acid 
hydrolysis; the aspartic acid detected by analysis could have originated from aspartic acid itself or from asparagine. Nevertheless, the molecular weight of the peptide, determined by mass spectrometry, indicated that it contained aspartic acid. As the $\mathrm{N}$-terminal residue identified by dansyl chloride reaction was aspartic acid, we might expect the structure of the peptide to be aspartyl lysine. As our peptide migrated as commercial $\alpha$-aspartyl $\varepsilon$-lysine, and not as commercial $\alpha$ aspartyl $\alpha$-lysine, it could be concluded that a pseudopeptide bond involving the $\varepsilon$-amino group of lysine was present.

These data do not clearly demonstrate whether the aspartic acid was engaged with its carboxyl function in the $\alpha$ or the $\beta$ position. As electrophoretic mobility of the dipeptide, aspartylglycine, was the same in both cases (fig. 3), the carboxyl function of the aspartic acid engaged in the bond could not be identified. Neither could we, as Welling and Groen (1978) did, determine this function from the colour obtained with ninhydrin since all the Asp-Lys dipeptides gave identical staining, probably due to the free amino group of lysine.

Origin of the peptide. - As the feces of axenic mice fed the protein-free diet did not contain our peptide, we supposed that the peptide had been released from the protein diet by endogenous proteolytic enzymes in the digestive

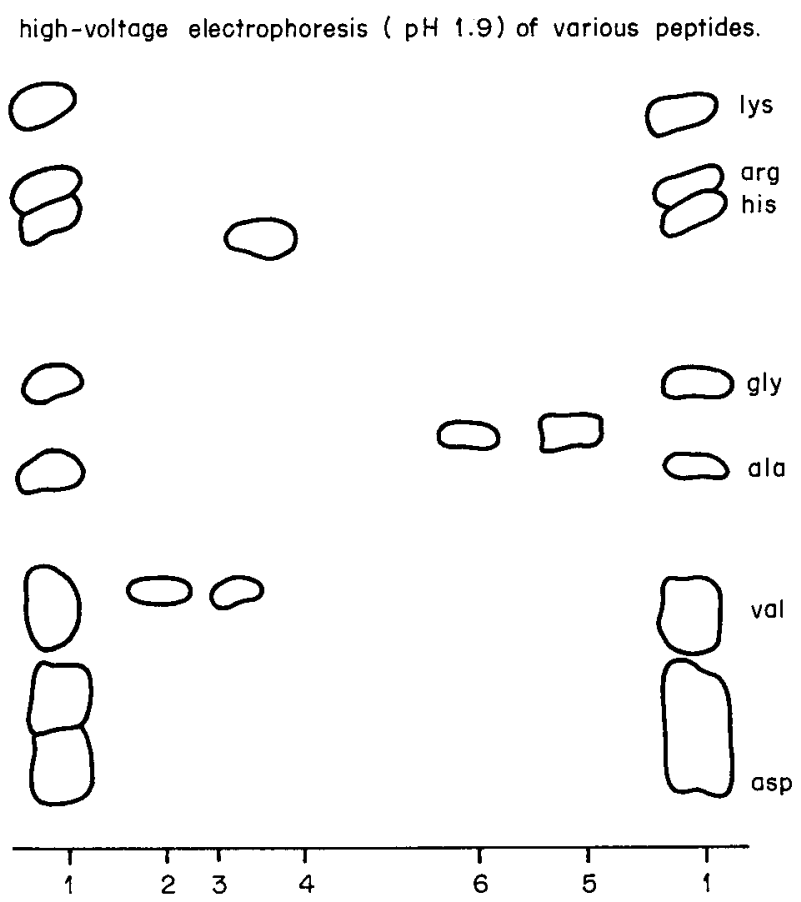

FIG. 3. - Paper electrophoretic migration ( $\mathrm{pH} 1.9)$ of different commercial peptides and of the peptide isolated from the fecal contents of axenic mice.

1. amino acid standard; 2. commercial $\alpha$-aspartylglycine ; 3 . commercial $\beta$-aspartylglycine ; 4. commercial $\alpha$-aspartyl $\alpha$-lysine ; 5 . commercial $\alpha$-aspartyl $\varepsilon$-lysine; 6. peptide isolated from the feces of axenic mice. 
tract during digestion and that because of the pseudopeptide bond, the animals could not absorb the product, which was eliminated in the feces.

A comparison of the two sterilization techniques, i.e. heat and irradiation, showed important differences in the peptide contents of the feces of axenic mice. When the diet was heated, large quantities of the product were obtained ; when it was irradiated, with little heat, we only obtained small amounts in the feces. We thus suppose that the presence of the peptide in the feces was to due heating. Pisano et al. (1960) and Asquith et al. (1970) detected the presence of $\varepsilon$ - $(\gamma$-glutamyl) lysine in heated fibrin and keratins. $\varepsilon-N-(\beta$-L-aspartyl) L-lysine is also suggested by Asquith et al. (1970) in the same products. Bjarnason and Carpenter $(1970)$ showed that, owing to a reaction between the $\varepsilon$-amino group of lysine and the amine group of asparagine, heating proteins causes the formation of a pseudopeptide bond. These results would indicate that our dipeptide was produced by such a reaction between asparagine and lysine when the proteins of the SN diet were heated. Therefore, we suggest that the structure of our peptide is $\beta$-L-aspartyl- $\epsilon$-L-lysine.

Effect of bacterial strains. - The presence of a complex microflora in the gut caused the peptide to disappear from the fecal content as observed for aspartylglycine (Welling et al., 1980). But the results obtained with gnotobiotic animals differed according to the bacterial strain used. This finding disagrees with those of Welling and Groen (1978) who concluded that 50 different bacterial strains were needed to make their peptide disappear. Consequently, the strain reacts differently, suggesting that intestinal strains vary in their ability to cleave in vivo the $\beta$-aspartyl-pseudopeptide bond.

Our results on another point disagree with those of Welling and Groen (1978) who concluded that the dipeptide, $\beta$-aspartylglycine, is " unique " in the cecal contents of germfree and antibiotic-treated mice. Furthermore, the electrophoretic mobility of their peptide did not correspond to that of our commercial $\beta$ aspartylglycine. Welling and Groen (1978) did not detect the presence of the other peptides we obtained, such as $\beta$-aspartyl- $\varepsilon$-lysine containing $\beta$-aspartyl residues. Our results indicate that it is possible to detect at least one other small peptide in the feces of axenic animals and that some Clostridium strains cannot hydrolyze peptides containing $\beta$-aspartyl residues. The discrepancy between our data and those of Welling et al. could be explained by differences in diet or in the bacterial strain used. The chemical methods employed to identify our product were also different from those of Welling et al.

Reçu en avril 1982.

Accepté en décembre 1982.

Acknowledgements. - We wish to thank Dr. Adda for the mass spectrometry of our product and Drs. Raibaud, Ducluzeau and Ribadeau-Dumas for fruitful discussion. 
Résumé. $\beta$-aspartyl-ø-lysine, un peptide du contenu faecal de souris axéniques.

Dans les fèces de souris axéniques alimentées avec un régime synthétique autoclavé, nous avons isolé un dipeptide de structure $\beta$-aspartyl- $\varepsilon$-lysine. Ce produit est également présent dans les fèces de souris gnotobiotiques abritant Clostridium perenne. Nous n'avons pas mis en évidence ce produit dans les fèces de souris holoxéniques ou de souris contaminées par Clostridium difficile, ni chez des souris axéniques ayant reçu un régime stérilisé par irradiation.

Le peptide, $\beta$-aspartyl- $\varepsilon$-lysine, peut être produit par chauffage durant la stérilisation par formation d'une liaison pseudo-peptidique entre le groupe $\varepsilon$ aminé de la lysine et la fonction amide de l'asparagine. Certaines souches bactériennes semblent capables d'hydrolyser une telle liaison alors que d'autres en sont incapables.

\section{References}

ASQUITH R. S., OTTERBUN M., BUCHANAN J. H., COLE M., FLETCHER J. C., GARDNER K. L., 1970. The identification of $\mathrm{E}-\mathrm{N}-(\gamma$-L-glutamyl) L-lysine cross-links in native wool keratins. Biochim. biophys. Acta, 221, 342-348.

BJARNASON J., CARPENTER K. J., 1970. Mechanisms of heat damage in proteins. Br. J. Nutr., 24, 313-320.

CHOPIN A., DUCLUZEAU R., RAIBAUD P., 1974. Effet du régime alimentaire sur l'équilibre entre 14 souches microbiennes ensemencées dans le tube digestif de souris axéniques adultes et sur l'établissement de ces souches chez leurs descendants entre la naissance et le sevrage. Can. J. Microbiol., 20, 1331-1339.

COMBE E., PENOT E., CHARLIER H., SACQUET E., 1965. Métabolisme du rat "Germfree ». Ann. Biol. anim. Bioch. Biophys., 5, 189-206.

DECUYPERE J., VAN DER HEYDE H., 1972. Study of gastrointestinal microflora of suckling piglets and early weaned piglets reared using different feeding systems. Zbl. Bakt. I. Abt., orig. A221, 492-510.

DUBOS F., 1982. Influence de deux régimes alimentaires complexes sur l'établissement de Clostridium perenne dans le tube digestif de souris gnotoxéniques. Th. Univ. Paris Sud.

DUCLUZEAU R., RAIBAUD P., LADIRE M., 1974. Cinétique de l'établissement d'une microflore anaérobie stricte dans le tube digestif de souriceaux nés de mères gnotoxéniques entre la naissance et le sevrage. Effet du régime alimentaire des mères. Ann. Microbiol. (Inst. Pasteur), 125A, 57-68.

DUCluzeAu R., RAIBAUd P., DUBOS F., CLARA A., LHUILleRY C., 1981. Remanent effect of some dietary regimens on the establishment of two Clostridium strains in the digestive tract of gnotobiotic mice. Am. J. clin. Nutr., 34, 520-526.

HARTLEY B. S., 1970. Strategy and tactics in proteins chemistry. Biochem. J., 119, 809-822.

PISANO J. J., FINLAYSON J. S., PEYTON M. P., 1968. Cross-link in fibrin polymerized by FACTOR XIII : $\varepsilon-(\gamma$-Glutamyl) lysine. Science, 160, 892-895.

SAVAGE D. C., 1977. Microbial ecology of gastrointestinal tract. Ann. Rev. Microbiol., 91, 107-133.

WELLING G. W., GROEN G., 1978. $\beta$-Aspartyl glycine, a substance unique to caecal contents of germ-free and antibiotic treated mice. Biochem. J., 175, 807-812.

WELLING G. W., GROEN G., TUINTE J. H. N., KOOPMAN J. P., KENNIS H. M., 1980. Biochemical effects on germ-free mice of association with several strains of anaerobic bacteria. J. gen. Microbiol., 117, 57-63. 